
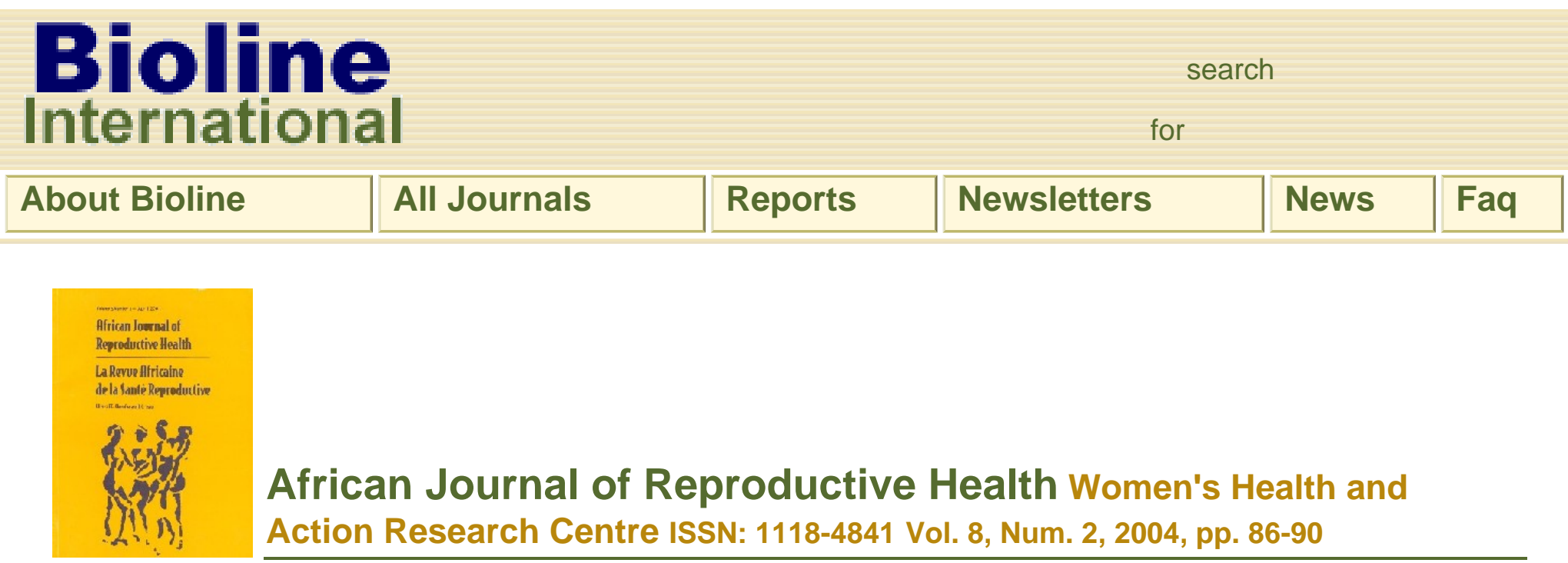

African Journal of Reproductive Health Women's Health and Action Research Centre ISSN: 1118-4841 Vol. 8, Num. 2, 2004, pp. 86-90

African Journal of Reproductive Health, Vol. 8, No. 2, Aug, 2004 pp. 86-90

\title{
Acceptance Rate of HIV Testing among Women Seeking Induced Abortion in Benin City, Nigeria
}

ME Enosolease ${ }^{1}$ and E Offor ${ }^{2}$

Departments of ${ }^{1}$ Haematology and ${ }^{2}$ Medical Microbiology, School of Medicine, College of Medical Sciences, University of Benin, Benin City, Nigeria.

Correspondence: Dr M. E. Enosolease, Department of Haematology, School of Medicine, College of Medical Sciences, University of Benin, Benin City, Nigeria.

\section{Code Number: rh04030}

\section{Abstract}

Although the campaign against HIV has been intensive, it has been focused mainly on the public health implications. Little or no attention is specifically directed at encouraging the public to know their HIV serostatus. The actual public health burden due to this infection is therefore not known. Accurate data on the health burden is critical for national planning on preventive and other interventional measures. Using a semi-structured self-administered questionnaire, we interviewed 1051 women seeking induced abortion in four randomly selected private clinics in Benin City between January and September 2002. The blood samples of those who accepted HIV testing were collected and screened at the University of Benin Teaching Hospital. The women were aged between 16 and 46 years (mean $31.1 \pm 6.7$ years). One hundred and thirty seven women (13\%) accepted HIV testing. Of the 1051 women, 1001 (95.2\%) had multiple sexual partners and $722(68.8 \%)$ regularly practiced unprotected sex. All were aware of HIV/ AIDS. The older women were more likely to accept voluntary HIV testing than the younger ones. Acceptance rate for voluntary HIV testing was low in both the employed and unemployed and much lower among full time housewives $(p=0.01)$. We therefore recommend that HIV 
campaign programmes should include strategies aimed at arousing public interest in voluntary HIV testing. (Afr J Reprod Health 2004; 8[2]: 86-90 )

Key Words: HIV testing, acceptance rate, women, abortion

\section{Résumé}

\section{Taux d'acceptation du test du VIH chez les femmes à la recherché de l'avortement} provoqué à Benin City, Nigeria. Qouique la campagne contre le VIH ait été intensive, elle a été concentré surtout sur les implications sur la santé publique. Pratiquement très peu d'attention a été consacrée à l'encouragement du public à connaître leur situation sérologique du VIH. Ainsi, le vrai degré du problème de la santé publique causé par cette infection n'est pas connu. Des données précises sur le problème de la santé sont critiques pour la planification nationale en ce qui concerne des mesures préventives et interventionnelles. A l'aide d'un questionnaire semi-structuré et auto-administré, nous avons interviewé 1051 femmes qui recherchaient l'avortement provoqué dans quatre cliniques selectionnées au hazard à Benin City entre janvier et septembre 2002. Les échantillons sanguins de celles qui ont accepté le test du VIH ont été collectés et ont été dépistés au Centre Hospitalier Universitaire de Benin City. Les femmes avaient entre 16 et 46 ans (moyenne 31, $1 \pm 6,7$ ans). Cent trente-sept femmes (13\%) avaient accepté le test du VIH. Parmi les 1051 femmes, 1001 (95,2\%) avaient des partenaires sexuels multiples et $722(68,8 \%)$ avaient systématiquement des rapports sexuels non-protégés. Elles étaient toutes conscientes du VIH/SIDA. Les femmes les plus âgées avaient plus de probabilité d'accepter volontairement le test du VIH que les femmes plus jeunes. Le taux d'acceptation pour le test du VIH était faible à la fois chez les femmes qui travaillent et chez celles qui ne travaillent pas, mais encore plus faible chez les femmes au foyer à plein temps $(p=0,01)$. Nous recommandons donc que les programmes de campagne contre le VIH comprennent des stratégies qui visent à susciter l'intérêt public dans le test du VIH volontaire. (Rev Afr Santé Reprod 2004; 8[2]: 86-90)

\section{Introduction}

The campaigns against HIV/AIDS have been intensive through various media and several fora. Such campaigns have been largely focused on its public health implications and healthy living. The impact of these campaigns on the willingness of people to know their HIV serostatus is minimal. Perhaps this aspect is being inadvertently subsumed into the general awareness campaign.

The attitudes and perceptions of the public regarding HIV testing may provide important information for the planning of preventive and interventional programmes. Several authors have advocated modalities of HIV testing. Some suggested mandatory testing and partner notification, voluntary counselling and testing (VCT) with or without notification, VCT with an "opt out" option, and unlinked anonymous testing. Arguments abound as to which of these methods is the best. ${ }^{1-6}$ 
Bioline International Official Site (site up-dated regularly)

(ANC) due to their concern for the health of the expected baby, self-perceived HIV risk, and knowledge of medical intervention to reduce disease symptoms or prevent vertical transmission. 7,8 It is not clear if the findings from these studies can be extrapolated to other population subgroups.

Providing an opportunity for individuals to know their HIV status is one of the strategies for addressing the HIV/AIDS epidemic that need to be focused on. In Uganda, for instance, reports have shown that VCT is a critical component of the national strategy to limit HIV transmission. ${ }^{1}$ Forsythe et al ${ }^{9}$ reported that more than $60 \%$ of the Kenyan population is willing to undertake VCT, largely due to the fear of annihilation by AIDS. Recent findings have shown increasing evidence that VCT can be an important resource for changing people's sexual behaviour. ${ }^{9}$

Abortion seekers are a high-risk group for HIV/AIDS and other sexually transmitted infections. Their decision to procure abortion definitely suggests that they engage in unprotected sexual intercourse, and possibly with multiple partners. Some of them at times present with a history of previous unsafe abortions. If sufficiently enlightened and counselled this group of persons could be used to influence their sex partners to seek VCT. Hence, this study sought to determine the willingness of this high-risk group to accept voluntary HIV testing.

\section{Methods}

Patients seeking termination of unplanned pregnancy were recruited from four randomly selected private general practice clinics in Benin City over a nine-month period (JanuarySeptember 2002). A simple self-administered questionnaire was used to obtain information on their sociodemographic characteristics, medical history, number of sexual partners in the last 12 months preceding the index interview, condom use, and awareness of HIV and its modes of transmission. The purpose of the study was explained to all the respondents in order to obtain their verbal consent. They were thereafter counselled on the importance of knowing their HIV sero-status. All those who consented to HIV screening requested and were assured of strict confidentiality after which they completed the questionnaire.

Blood sample $(5 \mathrm{ml})$ was collected from any prominent vein in the forearm of each of the respondents and put into a labelled plain bottle. Following clotting, the serum was removed into another serially labelled sterile bottle using a Pasteur pipette. All samples were tested for HIV antibodies at the UBTH using the rapid Welcozyme ELISA kit according to the procedure described by the manufacturer (Welcome Laboratories, Dartford, Germany). All sera were tested on the same day of collection. However, all repeatedly reactive samples were sent to the central Public Health Laboratory at Yaba, Lagos, for western blot confirmation.

\section{Definitions}

Employed women included those who were financially solvent. These were civil servants, businesswomen, artisans, etc. Unemployed women are those who were financially dependent like students, apprentices and secondary school leavers. 


\section{Exclusion Criteria}

Commercial sex workers (defined here as all those who had sex in exchange for money or other material gains) and those who had previously carried out HIV screening were excluded from the study.

\section{Statistical Analysis}

Simple percentages were used to determine the influence of age or occupation on HIV testing and voluntary counselling. Where necessary, we used Wilcoxsin test and chi-square $\left(x^{2}\right)$ to determine the effect of age or occupation on HIV testing rate and HIV sero-positivity. Statistical significance was set at $p=0.05$. All statistical analyses were carried out using INSTAT TM GRAPHPAD software version 2.05a.

\section{Results}

In order to assess the willingness of this high-risk group to accept voluntary HIV testing, we interviewed 1051 women seeking induced abortion over a period of nine months (January September 2002). All the 1051 respondents were aged between 16 and 46 years (mean $31.4 \pm$ 6.2 years) and all of them had a minimum of primary school education. A total of $1001(95.2 \%)$ admitted to having multiple sexual partners, and $722(68.7 \%)$ regularly practiced unprotected sex. Thirteen per cent $(n=137)$ of the respondents consented to anonymous HIV screening (request for anonymity precluded post-HIV test counselling). Of the screened 137 women, three were HIV-1 positive, representing 2.2\% prevalence. All respondents who refused HIV testing preferred not to know their HIV status for various reasons such as stigmatisation and social discrimination.

Table 1 shows the acceptance rate for HIV testing by age group. Acceptance increased from only $1.7 \%$ in women who were under 20 years of age to $47 \%$ in those above 40 years. For every additional five years in the respondents' age from age 30 years there was a corresponding increase of $14.5 \%, 19.8 \%$ and $47.4 \%$ in the acceptance of HIV testing. This was statistically significant $\left(x^{2}=54.38, \mathrm{df}=5, \mathrm{p}=0.0001\right)$. Table 2 compares the occupation of respondents and their acceptance rate for HIV testing. Full time housewives were the most unwilling to know their HIV status $(4.5 \%, n=117)$ while the employed and unemployed had acceptance rate for voluntary HIV testing of $13.1 \%(n=475)$ and $19.4 \%(n=359)$ respectively. Occupation appeared to have a strong influence on voluntary acceptance of HIV testing $\left(x^{2}=\right.$ 17.37, $\mathrm{df}=2, \mathrm{p}=0.0001)$. Three women were HIV-1 positive: one full time housewife, one employed and one unemployed.

\section{Discussion}

Voluntary HIV counselling and testing (VCT) should be a central component of comprehensive HIV prevention strategies. Data on VCT are essential for planning, budgeting and improving HIV/ AIDS interventions including manage-ment. ${ }^{1}$ The acceptance rate of $13 \%$ for voluntary HIV 
testing in this survey is rather low. This contrasts sharply with reports from other parts of the world including some African countries where voluntary HIV testing rate was between $80 \%$ and $96 \% .5,6,9,10$ This wide variation between our findings and other reports may be due to possible population bias of the two study groups. We report on abortion seekers while all the other reports were on antenatal patients. Indeed, Larson et al6 reported that the majority of prenatal women opted for VCT in consideration of their unborn children especially for the fear of vertical transmission. Unlike the prenatal patients, our study population had no consideration for fetal well being. Furthermore, the abortion seekers were rarely counselled for voluntary HIV testing or mandated to do HIV screening before induced abortions are carried out on them.

We also report the impact of occupation on the willingness of this group of women to accept VCT. We found better acceptance of voluntary HIV testing among the unemployed than the employed (19.4\% vs. $13.1 \%)$. This finding is contrary to previous reports that showed good correlation between the employed and high acceptance rate of HIV voluntary testing. ${ }^{11,12}$ These reports also showed low acceptance rate of HIV testing among the unemployed. The mostprobable reason for the poorer acceptance rate among the employed in our study may be the fear of losing their job if they were found to be HIV positive.

The full time housewives in the study demonstrated very poor willingness to accept HIV voluntary testing and counselling. There have been no consensus about the willingness of full time housewives to accept voluntary HIV screening. ${ }^{11,12}$ While some authors reported very high acceptance rate among full time housewives others reported very low rate among the same group of women. ${ }^{12,13}$ Our finding in this study is in agreement with latter reports, which may be due to the fear of break-up of families or domestic violence, particularly in HIV discordant couples. ${ }^{13}$

Other reasons may also be responsible for the low acceptance rate of HIV screening such as poor knowledge of the disease and its mode of transmission, individual fear of discrimination and stigmatisation, notification, inability to afford treatment, anxiety during the period of waiting for the results, or even the fear of venepuncture. ${ }^{14-15}$

Our major challenge in this study was the insistence of respondents on strict confidentiality, which precluded post-test counselling. Post-test counselling might have provided the opportunity to re-assure HIV positive respondents and encourage those with negative results on the need for preventive measures and risk reduction strategies.

We suggest that enlightenment campaigns that will include strategies to encourage people to undertake voluntary HIV screening be carried out.

\section{References}

1. UNAIDS. Knowledge is Power: Voluntary HIV Counseling and Testing in Uganda. Geneva: UNAIDS, 1999.

2. Kawichai S, Celentano DD, Chaifongsri R, Nelson KE, Srithanaviboochai K, et al. Profile 
of HIV voluntary counseling and testing of clients at a district hospital, Chiang Mai Province, Northern Thailand, from 1995 to 1999. J Acquir Immune Def Syndr 2002; 30 (5): 493-502.

3. Meda N, Zoundi-Guigui MT, van de Perre P, Alary M, Ouangre A, et al. HIV infection among pregnant women in Bobo-Dioulasso, Burkina Faso: comparison of voluntary and blinded seroprevalence estimates. Int J STD AIDS 1999; 10(11): 738-740.

4. Gruslin A, Saivador A, Dekker M, Menard-de Varennes D and Eason E. Prenatal HIV screening in a tertiary care center. Can J Public Health 2001; 92(4): 255-258.

5. Jayaraman GC, Preiksaitis JK and Larke B. Mandatory reporting of HIV infection and opt-out prenatal screening for HIV infection: effects on testing rates. CMAJ 2003; 168 (6): 679-82.

6. Robbins AS, Jablonski CL, Mitchell BE, King SA, Melvile SK and Stanley SK. Parental HIV testing in private OB-Gyn pratices in Texas. Tex Med 2002; 98(5): 50-55.

7. Larsson G, Spangberg L, Lindgren S and Bohlin AB. Screening for HIV in pregnant women:a study of maternal opinion. AIDS Care 1990; 2(3): 223-228.

8. Heckkert KA, Bagshaw S, Fursman L, Kipa M, Wilson M, et al. Women's acceptability of screening for HIV in pregnancy. NZ Med J 2001; 114(1144): 509-512.

9. Forsythe S, Arthur G, Ngatia G, Mutemi R, Odhiambo J and Gilks C. Assessing the cost and willingness to pay for voluntary HIV counseling and testing in Kenya. Health Policy Plan 2002; 17(2): 187-195.

10. Tse HY, Lai FK, Wong J, Chan AS and Tang LC. Universal screening of human immunodeficiency virus infection in pregnant women in Hong Kong: prospective study. Hong Kong Med J 2001; 7(3): 246-250.

11. Kowalczyk J, Jolly P, Karita E, Nibarere JA Vyankandondera J and Salihu H. Voluntary counseling and testing for HIV among pregnant women presenting in labour in Kigali, Rwanda. J Acquir Immune Defic Syndr 2002; 31(4): 408-415.

12. Pool R, Nyanzi $S$ and Whitworth JA. Attitudes to voluntary counseling and testing for HIV among pregnant women in rural south-west Uganda. AIDS Care 2001; 13(13): 605615.

13. Akpede GO, Lawal RS and Momoh SO. Perception of voluntary screening for paediatric HIV and response to post-test counseling by Nigerian parents. AIDS Care 2002; 14(5): 683-697.

14. Spielberg F, Branson BM, Goldbaum GM, Lockhart D, Kurth A, et al. Overcoming barriers to HIV testing; preferences for new strategies among clients of a needle exchange, a sexually transmitted disease clinic, and sex venues for men who have sex with men. J Acquir Immune Defic Syndr 2003; 32(3): 318-327.

15. Erwin J, Morgan M, Britten N, Gray K and Peters B. Pathways to HIV testing and care by black Africans and white patients in London. Sex Transm Infect 2002; 78(1): 37-39.

(C) Women's Health and Action Research Centre 2004 


\section{The following images related to this document are available:}

Photo images

[rh04030t1.jpg] [rh04030t2.jpg]

\begin{tabular}{|c|c|c|c|}
\hline Home & Resources & Mailing List & Email Bioline \\
\hline
\end{tabular}




\section{Table 1 Age Distribution and Acceptance of HIV Testing}

\begin{tabular}{lcccc}
\hline Age (years) & $\begin{array}{r}\text { Accepted HIV } \\
\text { testing }\end{array}$ & $\begin{array}{r}\text { Refused HIV } \\
\text { testing }\end{array}$ & Total & $\begin{array}{r}\text { Percentage } \\
\text { acceptance }\end{array}$ \\
\hline$<20$ & 4 & 229 & 233 & 1.7 \\
$20-24$ & 37 & 201 & 238 & 15.5 \\
$25-29$ & 32 & 219 & 251 & 12.7 \\
$30-34$ & 29 & 150 & 179 & 14.5 \\
$35-39$ & 26 & 105 & 131 & 19.8 \\
$\geq 40$ & 9 & 10 & 19 & 47.4 \\
\hline Total & 137 & 914 & 1051 & 13.0 \\
\hline$p=0.0001$ & $\left(\chi^{2}=54.4 ; d f=5\right)$ & & &
\end{tabular}


Relationship of Occupation with Acceptance of HIV Voluntary Testing and Counselling

\begin{tabular}{lrrrr}
\hline Occupation & $\begin{array}{r}\text { Accepted HIV } \\
\text { testing }\end{array}$ & $\begin{array}{r}\text { Refused HIV } \\
\text { testing }\end{array}$ & Total & $\begin{array}{r}\text { Percentage } \\
\text { acceptance }\end{array}$ \\
\hline Full time housewives & 5 & 112 & 117 & 4.5 \\
Employed & 62 & 413 & 475 & 13.1 \\
Unemployed & 70 & 289 & 359 & 19.1 \\
\hline Total & 137 & 914 & 1051 & 13.0 \\
\hline$p=0.0001 \quad\left(\chi^{2}=17.37 ; d f=2\right)$ & & &
\end{tabular}

